\title{
Effects of Diabetes Mellitus on the Reproductive System of Adult Male Mice After One Cycle of Spermatogenesis
}

\author{
Kouassi Emile Bégbin \\ N'Guessan Ernest Zougrou \\ Georges Abizi \\ Koffi Kouakou \\ N'Takpé Emmanuel Jaurès Mangué \\ University of Félix Houphouet-Boigny, Faculty of Biosciences, Laboratory \\ of Biology and Health, Ivory Coast
}

Doi:10.19044/esj.2021.v17n34p149

Submitted: 06 August 2021

Accepted: 25 August 2021

Published: 30 September 2021
Copyright 2021 Author(s)

Under Creative Commons BY-NC-ND 4.0 OPEN ACCESS

Cite As:

Bégbin K.E., Zougrou E.N`G., Abizi G., Kouakou K. \& Mangué N.E.J. (2021). Effects of Diabetes Mellitus on the Reproductive System of Adult Male Mice After One Cycle of Spermatogenesis. European Scientific Journal, ESJ, 17(34), 149.

https://doi.org/10.19044/esj.2021.v17n34p149

\section{Abstract}

Background: Diabetes mellitus is a disease characterized by chronic hyperglycemia. Poor management of hyperglycemia leads to complications that can reduce quality of life. Diabetes mellitus has been associated with damage to the reproductive system. The present study examines effects of diabetes mellitus on the reproductive system in alloxan-induced diabetic mice after one cycle of spermatogenesis.

Materials and Methods: Twelve (12) mice divided into "control" and "diabetic" groups of six (6) animals each were used. Diabetes was induced in adult male mice by intraperitoneal injection with a single dose of $220 \mathrm{mg} / \mathrm{kg}$ body weight of alloxan. After 40 days, sperm density, morphology, and motility were assessed by standard methods. Serum levels of testosterone, FSH, and LH were measured. In addition, testes and epididymis were removed for histological study.

Results: Highly significant $(\mathrm{P}<0.001)$ reductions in serum testosterone, FSH, and LH levels, as well as normal and motile sperm counts of $21 \%$ and $34 \%$ respectively were observed in the diabetic group. The control group had three times more sperm than the diabetic group. The histological 
study showed that diabetic animals had atrophied seminiferous tubules, increased inter-tubular spaces, loss of interstitial tissue, degeneration of seminiferous tubules, and almost complete reduction of sperm count in the epididymal duct.

Conclusion: Chronic hyperglycemia is therefore deleterious to the male reproductive system of mice. It leads to hypogonadism, which causes dysfunction of the male reproductive system, and can lead to infertility in men with diabetes mellitus.

Keywords: Reproductive System, Diabetes Mellitus, Spermatogenesis

\section{Introduction}

Diabetes mellitus is the most common endocrine disease and one of the most common chronic disorders (Wherrett et al., 2018). It is a condition characterized by chronic hyperglycemia (Punthakee et al., 2018). The International Diabetes Federation (IDF) estimates that 463 million people were living with diabetes mellitus in 2019. This number is expected to rise to 578 million by 2030 and 700 million by 2045 (IDF, 2019). Poor management of high blood glucose in people with diabetes have led to complications that can significantly reduce their quality of life. Diabetes mellitus has been associated with reproductive system impairment in both men and women (Shojaeii et al., 2014). However, a recent study showed that hypogonadism is common in men with diabetes mellitus, and the prevalence is as high as $40 \%$ for type 2 diabetes (Bebb et al., 2018). This deficit in sex hormone secretion is thought to be responsible for the erectile dysfunction and spermatogenesis disturbance observed in diabetic men (Jangir \& Jain, 2014; Ding et al., 2015). Hypogonadism has been shown to negatively impact the quality of life of men, irrespective of age, with a greater impact in men with permanent, rather than intermittent, erectile dysfunction (Rosen et al., 2004; Corona et al., 2013; Maiorino et al., 2017). In addition, diabetic men with hypogonadism have an increased risk of cardiovascular mortality compared to eugonadal men with diabetes (Bebb et al., 2018).

Although hypogonadism is well recognised as a complication of diabetes, infertility among diabetic men is a lesser examined problem, and the assessment of gonadal status is not clearly established. Alloxan-induced diabetic mice are widely used to study the effect of diabetes mellitus on fertility (Carvalho et al., 2003; Arikawe et al., 2006; Gumieniczek \& Wilk, 2009). The present study examines effects of diabetes mellitus on the male reproductive system of alloxan-induced diabetic mice after one cycle of spermatogenesis (34 days for mice). Specifically, it aims to analyse serum levels of testosterone and pituitary gonadotropins, sperm parameters, testicular weight, and the condition of testicular and epididymal tissue. 


\section{Materials and Methods Experimental Animals}

Adult male Swiss mice were used in this study. They were 10 to 12 weeks old and weighed between 28 and $32 \mathrm{~g}$. These animals were bred in the vivarium of the "École Normale Supérieure" in Abidjan (Ivory Coast). They were housed and maintained at a constant temperature of $27-29^{\circ} \mathrm{C}$ with a relative humidity of $65 \%$ and standard $12: 12 \mathrm{~h}$ light-darkness cycles. Animals were handled according to the guidelines of the Ethical Committee on the use and care of experimental animals of the Department of Biosciences, Université Félix Houphouët-Boigny, Ivory Coast.

\section{Induction of Diabetes}

Animals were deprived of food for 16 hours. Diabetes was induced by intraperitoneal injection of a single dose of $220 \mathrm{mg} / \mathrm{kg}$ body weight (BW) of alloxan dissolved in isotonic solution $(0.9 \% \mathrm{NaCl})$. Animals developed diabetes after 3 days. Mice with blood glucose level of $3 \mathrm{~g} / \mathrm{L}$ (clinical diabetes $\geq 1.26 \mathrm{~g} / \mathrm{L}$ ) or higher were selected for the study.

\section{Experimental Design}

Mice were divided into two (2) groups of six (6) animals as follows:

- Group 1: Healthy mice (control);

- Group 2: Diabetic mice.

They were housed in groups of 3 animals. They had free access to standard rodent chow and tap water ad libitum for 40 days. At the end of the experiment, animals were anesthetized with ether in order to collect spermatozoa for analysis of sperm parameters. Blood samples were collected in dry tubes for the determination of serum testosterone, FSH, and $\mathrm{LH}$ concentrations. In addition, testes and epididymis were immediately removed, weighed, and fixed in $10 \%$ formalin for histological study.

\section{Blood Glucose Level and Body Weight Measurements}

Animals were fasted prior to the determination of blood glucose level and body weight. Values were recorded weekly, and blood glucose estimation was performed with an On Call ${ }^{\circledR}$ Extra test strip meter (USA). Blood samples were collected from the tail end of the mice.

\section{Sperm Collection}

Animals were anesthetized with ether. The tail of the left epididymis was collected by opening the scrotum, and then dilated in $5 \mathrm{~mL}$ of $9 \% \mathrm{NaCl}$ previously incubated in a water bath at $36^{\circ} \mathrm{C}$. Thus the spermatozoa diffused into the solution (Ngoula et al., 2007). 


\section{Sperm Motility}

A fine drop of epididymis macerate was placed and spread lightly on a slide previously maintained at $36^{\circ} \mathrm{C}$. The slide was mounted on a light microscope (Olympus CX31RBSF, Philippine) at $\times 100$ magnification. The sperm were filmed with an AmScope (SN: 1605261081) camera (London, United Kingdom). Motile and immobile sperm were subsequently counted on 5 random fields, and the percentage of motile forms was determined (Zougrou et al., 2018).

\section{Sperm Cell Concentration}

A drop of epididymis macerate was collected and deposited on a Malassez cell and covered with a cover slip. The sperm count was performed under a light microscope (magnification $\times 400$ ). The number of sperm per $\mathrm{mm}^{3}$ was estimated by the following formula (Sultan et al., 1982):

$$
N=\frac{X \times f d \times 10^{6}}{4}
$$

$\mathrm{X}$ : Number of sperm counted in 5 grids of the Malassez cell

fd: Dilution factor (20)

$\mathrm{N}$ : Number of sperm per $\mathrm{mm}^{3}$

\section{Sperm Morphology}

Sperm morphological abnormalities include fusion, isolated heads, and deformed heads and/or tails (OECD 416, 2001). Two hundred (200) sperm were examined in liquid medium on 3 random fields. The percentage of normal sperm was calculated (Linder et al., 1992).

\section{Serum FSH, LH and Testosterone Measurements}

Pituitary gonadotropins (FSH and LH) and testosterone were determined using the Hitachi 902 (Japan) ELFA (Enzyme Linked Fluorescent Assay) technique.

\section{Histological Study}

Testicles and the right caudal epididymis were removed and fixed in $10 \%$ formalin. After 72 hours, they were dehydrated and cleared in alcohol $\left(80^{\circ}, 90^{\circ}\right.$ and $\left.100^{\circ}\right)$ and toluene (99.5 \%) baths respectively. Each organ was impregnated and embedded in paraffin. The whole set was cut at $5 \mu \mathrm{m}$ with a microtome (Leica RM2125 RTS, Germany). The resulting sections were stained in Harris haematoxylin and eosin solutions respectively. Mounting them using Eukitt allowed their good readability under a light microscope (Olympus CK41SF, Philippines) (Zougrou et al., 2018). The installation of a 
camera connecting the microscope to a computer allowed image taking via AmScope 3.7 software (London, United Kingdom).

\section{Statistical Analysis}

Different values obtained were expressed as the mean, followed by the standard error of the mean $(\mathrm{M} \pm \mathrm{SEM})$. The significance of differences observed between groups of animals was assessed by the Student's T-test using GraphPad Prism 7.03 software (San Diogo California, USA).

\section{Results}

\section{Changes in Blood Glucose Concentration and Body Weight}

Figure 1 shows the time course of basal blood glucose levels in control and diabetic groups. At the beginning of the experiment, the basal blood glucose levels of the diabetic mice $(3.62 \pm 0.13 \mathrm{~g} / \mathrm{L})$ were significantly elevated $(\mathrm{P}<0.001)$ compared to the control $(0.70 \pm 0.01 \mathrm{~g} / \mathrm{L})$. These blood glucose levels remained statistically stable until the end of the experiment. The body weight of control animals increased during the experiment while that of the diabetic mice decreased. Control mice had a weight gain of $21.62 \%$ compared to a loss of $27.46 \%(\mathrm{P}<0.001)$ in diabetic mice (Figure 2$)$.

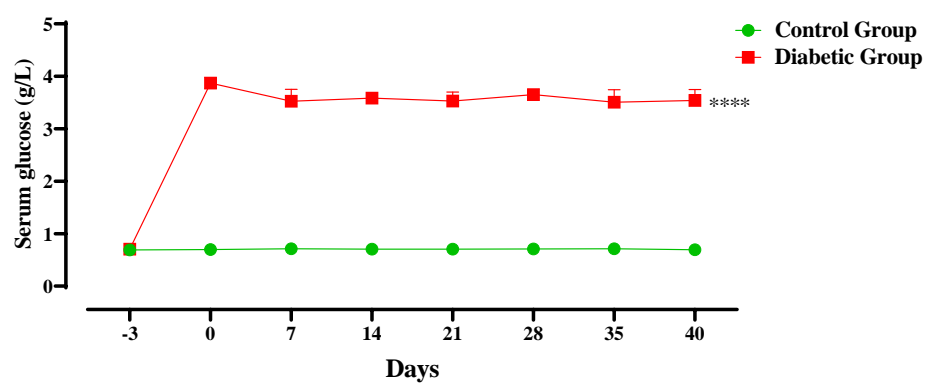

Figure 1. Changes in Serum Glucose Concentration in Experimental Groups during the Experiment

Comparison control group and diabetic group, (Mean \pm SEM), $(\mathrm{n}=6)$. **** $\mathrm{p}<0.0001$

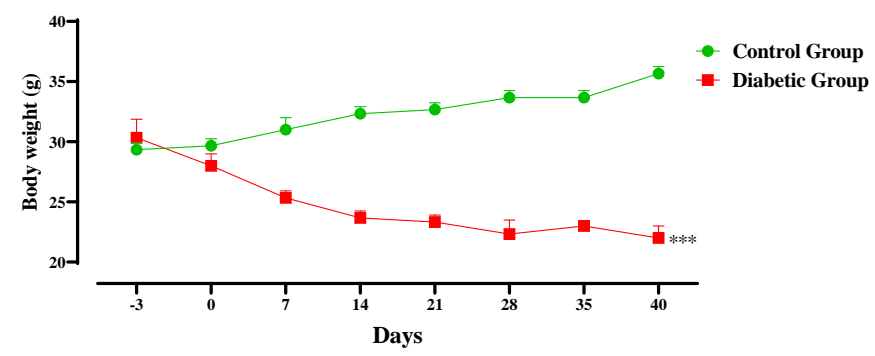

Figure 2. Changes in Body Weight in Experimental Groups during the Experiment Comparison control group and diabetic group, (Mean \pm SEM), $(n=6) .{ }^{* * *} \mathrm{p}<0.001$. 


\section{Testicular Weight and Serum FSH, LH and Testosterone Levels}

Testicular weights of diabetic animals $(0.68 \pm 0.03 \mathrm{~g})$ were significantly lower $(\mathrm{P}<0.5)$ than those of healthy animals $(0.79 \pm 0.02 \mathrm{~g})$, a decrease of $16 \%$ (Figure 3). Diabetic mice had significantly $(\mathrm{P}<0.001)$ lower levels of sex hormones than the control group. Indeed, the serum testosterone level of the diabetic group was 24.28 times lower than that of the control group. The FSH and LH levels of these diabetic animals were 4.15 and 3.93 times lower than those of the control group respectively (Table I).

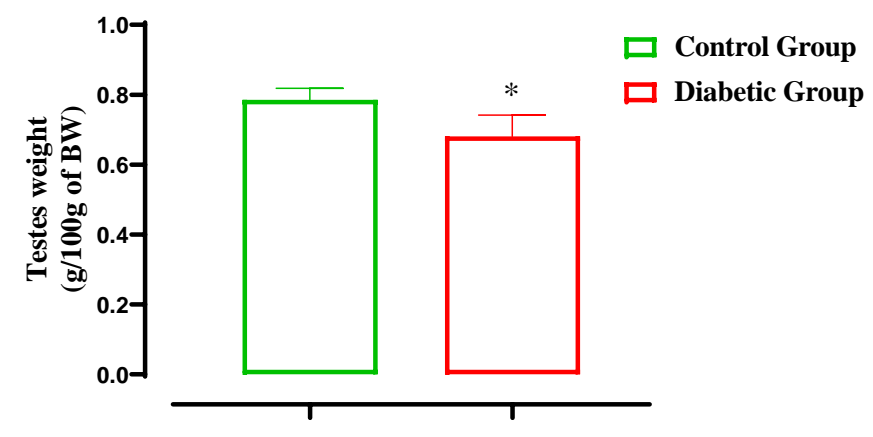

\section{Groups}

Figure 3. Testes Weight in Experimental Groups

Comparison between control group and diabetic group, (Mean \pm SEM), $(n=6)$.

$$
{ }^{*} \mathrm{p}<0.05
$$

Table I. Blood Concentrations of Testosterone, FSH and LH in Experimental Groups

\begin{tabular}{|c|c|c|}
\hline \multirow{2}{*}{} & \multicolumn{2}{|c|}{ Groups } \\
\cline { 2 - 3 } & Control group & Diabetic group \\
\hline Testosterone (ng/mL) & $1.603 \pm 0.077$ & $0.066 \pm 0.008^{* * * *}$ \\
\hline FSH (UI/mL) & $0.137 \pm 0.007$ & $0.033 \pm 0.003 * * *$ \\
\hline LH (UI/mL) & $0.247 \pm 0.009$ & $0.063 \pm 0.007 * * * *$ \\
\hline
\end{tabular}

Comparison between control group and diabetic group, (Mean \pm SEM), $(n=6) .{ }^{* * *} \mathrm{p}<0.001$, $* * * * \mathrm{p}<0.0001$

\section{Sperm Parameters}

The control group had 3 times more sperm than the diabetic group (Figure 4). Significant $(\mathrm{P}<0.001)$ reductions of $21 \%$ and $34 \%$ in normal and motile sperm counts respectively were observed in diabetic mice compared to healthy mice (Figures 5 and 6). 


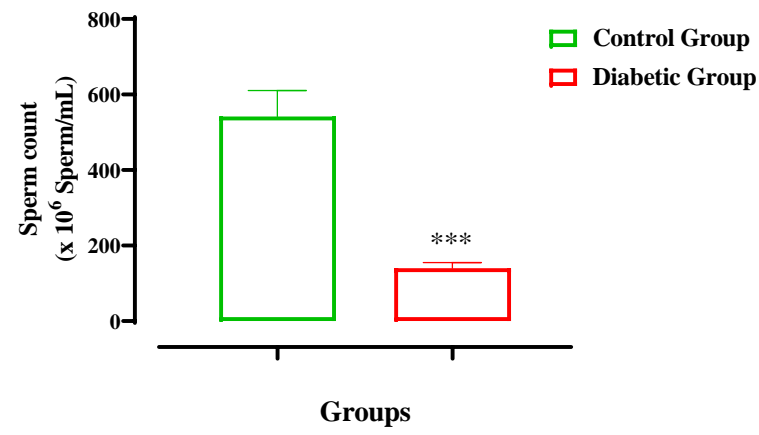

Figure 4. Sperm Count in Experimental Groups

Comparison control group and diabetic group, (Mean \pm SEM), $(n=6) .{ }^{* * *} \mathrm{p}<0.001$

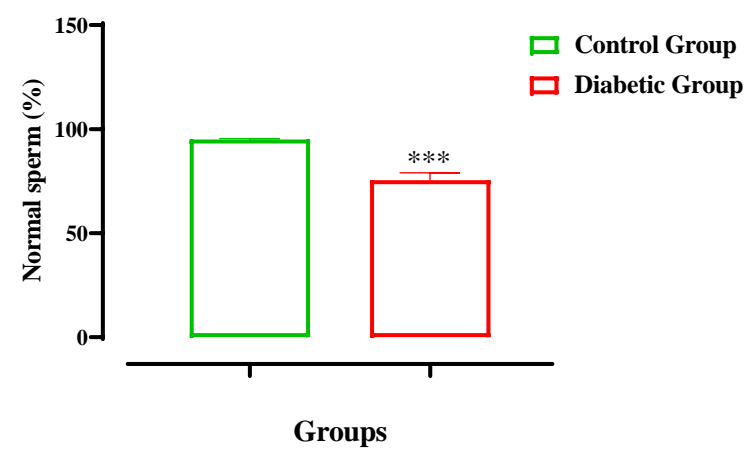

Figure 5. Normal Sperm in Experimental Groups

Comparison control group and diabetic group, $\left(\right.$ Mean \pm SEM), $(n=6),{ }^{* * *} \mathrm{p}<0.001$

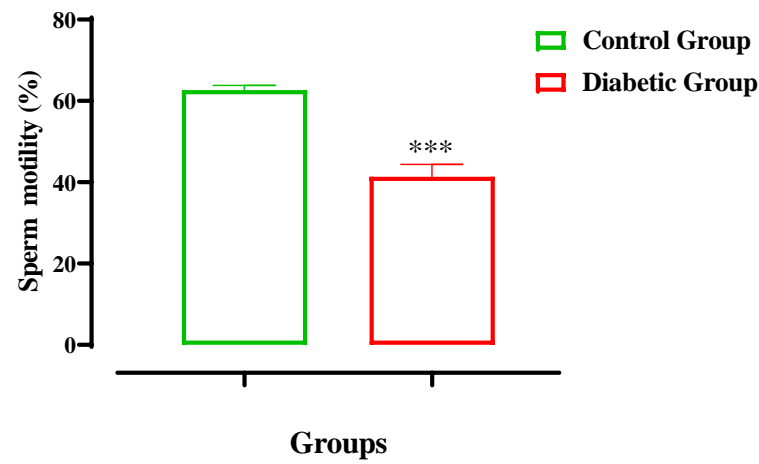

Figure 6. Sperm Motility in Experimental Groups

Comparison control group and diabetic group, (Mean \pm SEM), $(n=6) .{ }^{* * *} \mathrm{p}<0.001$

\section{Histological Study}

Figure 7 shows cross sections of testes and epididymis of healthy and diabetic mice. Seminiferous tubules of healthy mice were intact. Different stages of spermatogenesis were observed. Interstitial tissue was present. In 
contrast, seminiferous tubules of diabetic animals were atrophied. There was also an increase in inter-tubular spaces, loss of interstitial tissue, and degeneration of seminiferous tubules. As for the epididymis, an almost complete reduction in the number of spermatozoa in its duct was observed in diabetic animals compared to healthy animals.
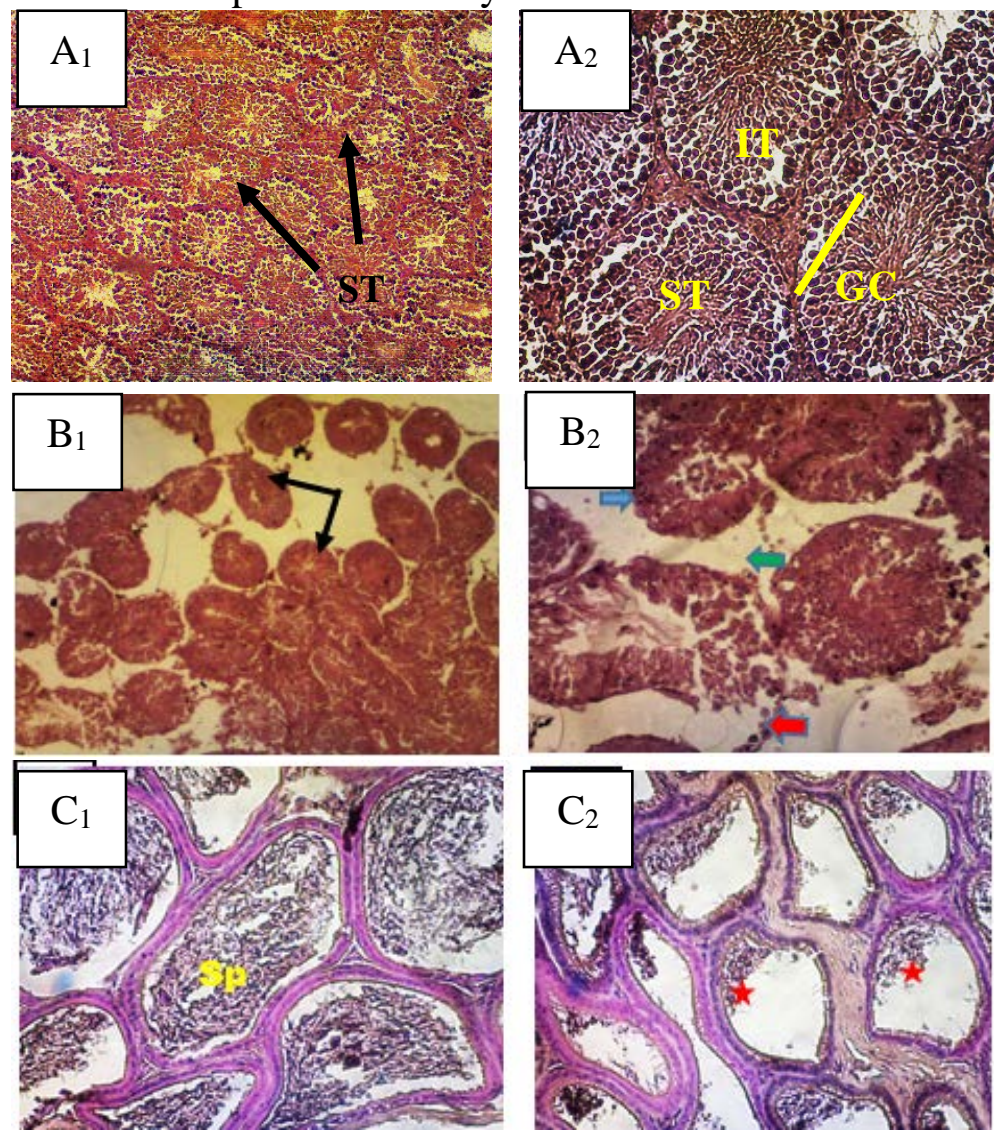

Figure 7. Cross Section of Testicular Tubules and the Epididymis in Experimental Groups $A_{1}$ and $A_{2}$ : Seminiferous tubules of the control group; $B_{1}$ and $B_{2}$ : Seminiferous tubules of the diabetic group; C: Epididymis of the control group; D: Epididymis of the diabetic group;

ST: Seminiferous tubules; IT: Interstitial Tissue; GC: Germ Cells; Sp: Sperm. Tubular atrophy (blue arrows); Increase of intercellular space (green arrows); Degeneracy of seminiferous tubules (red arrows); reduction of sperm population (red asterisks). $A_{1}$ and $B_{1}$ Magnification: $\times 100 ; A_{2}, B_{2}, C$ and $D$ Magnification: $\times 400$;

Hematoxylin and Eosin Staining

\section{Discussion}

This study was performed to examine effects of diabetes mellitus on the male reproductive system of mice after one cycle of spermatogenesis. Chronic hyperglycemia was induced by alloxan. Alloxan is a drug widely used to induce experimental diabetes. It selectively destroys $\beta$-cells of pancreatic 
islets (Szkudelski, 2001; Soltésová \& Herichová, 2011). In contrast to streptozotocin, it seems that the change that appears in other organs after alloxan administration is related to chronic hyperglycemia and not to alloxan (Bolzan \& Bianchi, 2002). In this study, the blood glucose level of the diabetic group was significantly higher than the control group. This is due to a decrease in serum insulin levels as a consequence of the destruction of pancreatic islet $\beta$-cells. In addition, the body weight of diabetic animals decreased during the experiment while that of the control group increased. This weight loss can be explained by an increase in gluconeogenesis in diabetic subjects. Indeed, insulin deficiency leads to an increase in serum levels of counter-regulatory hormones (glucagon, catecholamines, cortisol and growth hormone) (Meyer et al., 1998). These hormones induce lipolysis and lead to an increase in the serum concentration of gluconeogenesis precursors.

Serum FSH, LH and testosterone concentrations in the diabetic group were significantly lower than in the control group. This result is consistent with the literature (Murray et al., 1981; Steger et al., 1989; Ballester et al., 2004). Yogev et al. (1985) even noted a systematic decrease in serum LH level in diabetic animals from the second day of diabetes. The reduction in pituitary gonadotropin level is thought to be due to a decrease in GnRH level. Indeed, results of a GnRH stimulation test on the pituitary in diabetic rats showed a blunted response (Seethalakshmi et al., 1987).

Thus, a decrease in the expression of LH associated with that of insulin in the testicular tissue leads to a dysfunction of the Leydig cells, and thus a defect in testosterone secretion. Hypogonadism would therefore be one of the potential causes of the decrease in sperm count and normal mobile sperm rates observed in the diabetic group. However, oxidative stress caused by chronic hyperglycemia is thought to be the major cause of testicular damage. Indeed, previous work indicated that oxidative stress damages sperm nuclear and mitochondrial DNA (Amaral et al., 2006; Aitken \& Kopper, 2011; Kotian et al., 2019). Spermatozoa are highly vulnerable to oxidative attack as they lack significant antioxidant protection due to the limited volume and distribution of cytoplasmic space in which an appropriate armoury of defensive enzymes is housed (hyaluronidase, acid proteinases, arylsulfatase, ribonuclease, alkaline phosphatase). In particular, sperm membrane lipids are sensitive to oxidative stress because they are rich in polyunsaturated fatty acids. The susceptibility to oxidative attack is further exacerbated by the fact that these cells actively generate reactive oxygen species (ROS) to stimulate the increased tyrosine phosphorylation associated with sperm capacitation.

However, this positive role for ROS is reversed when sperm are stressed. Under these conditions, they default to an intrinsic apoptotic pathway characterised by mitochondrial ROS generation, loss of mitochondrial membrane potential, caspase activation, exposure to phosphatidylserine, and 
oxidative DNA damage (Aitken et al., 2016). Thus, cessation or dysfunction of spermatogenesis leads to reduced sperm count and increased numbers of abnormal and immobile sperm. Delfino et al. also showed that diabetes mellitus alters sperm parameters and affects sperm quality (Delfino et al., 2007). The alteration of sperm parameters is corroborated by the analysis of histological sections of the testes and epididymis of diabetic animals. Indeed, seminiferous tubules of diabetic animals were atrophied. There was also an increase in inter-tubular spaces, a loss of interstitial tissue, and degeneration of seminiferous tubules. An almost complete reduction in sperm count was observed in the duct of the epididymis. Thus, the decrease in testicular weight is related to the decrease in the number of germ and somatic cells in testicles. Comparable results have been reported by Shojaeii et al. and Kianifard (Shojaeii et al., 2014; Kianifard, 2016).

\section{Conclusion}

In conclusion, chronic hyperglycemia is deleterious to the male reproductive system of mice. Hypogonadism, which might be associated with oxidative stress and caused by this persistent hyperglycemia, induce a decrease in sperm count, normal and motile sperm counts and testes weight, alteration of sperm parameters, atrophy, and degeneration of seminiferous tubules. This can lead to infertility in men with diabetes mellitus (by extension of this study to men).

\section{References:}

1. Aitken, R. J., Gibb, Z., Baker, M. A., Drevet, J. \& Gharagozloo, P. (2016). Causes and consequences of oxidative stress in spermatozoa. Reproduction, Fertility and Development, 28: 1-0.

2. Aitken, R. J. \& Kopper, A. J. (2011). Apoptosis and DNA damage in human spermatozoa. Asian Journal of Andrology, 13: 36-42.

3. Amaral, S., Moreno, A. J., Santos, M. S., Seiça, R., Ramalho-Santos, J. (2006). Effects of hyperglycemia on sperm and testicular cells of Goto-Kakizaki and streptozotocin-treated rat models for diabetes. Theriogenology, 66: 2056-2067.

4. Arikawe, A. P., Daramola, A. O., Odofin, A. O. \& Obika, L. F. (2006). Alloxan-induced and insulin-resistant diabetes mellitus affect semen parameters and impair spermatogenesis in male rats. African Journal of Reproductive Health, 10: 106-113.

5. Ballester, J., Munoz, M. C., Domínguez, J., Rigau, T., Guinovart, J. J., Rodríguez-Gil, J. E. (2004). Insulin-dependent diabetes affects testicular function by FSH- and LH-linked mechanisms. Journal of Andrology, 25: 706-719. 
6. Bebb, R., Millar, A. \& Brock, G. (2018). Dysfonction sexuelle et hypogonadisme chez les hommes diabétiques. Canadian Journal of Diabetes, 42: 28-33.

7. Bolzan, A. D. \& Bianchi, M. S. (2002). Genotoxicity of streptozotocin. Mutation Research. 512:121-134.

8. Carvalho, C. A., Camargo, A. M., Cagnon, V. H. \& Padovani, C. R., (2003). Effects of experimental diabetes on the structure and ultrastructure of the coagulating gland of C57BL/6J and NOD Mice. The Anatomical Record. Part A, Discoveries in Molecular, Cellular, and Evolutionary Biology, 270: 129-136.

9. Corona, G., Giorda, C. B., Cucinotta, D., Guida, P., Nada, E. \& the SUBITO-DE study group, (2013). The SUBITO-DE study: Sexual dysfunction in newly diagnosed type 2 diabetes male patients. Journal Endocrinological Investigation, 36: 864-868.

10. Delfino, M., Imbrogno, N., Elia, J., Capogreco, F. \& Mazzilli, F. (2007). Prevalence of diabetes mellitus in male partners of infertile couples. Minerva Urology and Nephrology, 59: 131-135.

11. Ding, G-L., Liu, Y., Liu, M-E., Pan, J-X., Guo, M-X., Sheng, J-Z. \& Huang, H-F. (2015). The effects of diabetes on male fertility and epigenetic regulation during spermatogenesis. Asian Journal of Andrology, 17: 948-953.

12. IDF (2019). L’Atlas du diabète de la Fédération Internationale du Diabète. $9^{\text {ème }}$ Edition: 176p.

13. Gumieniczek, A. \& Wilk, M. (2009). Nitrosative stress and glutathione redox system in four different tissues of alloxan-induced hyperglycemic animals. Toxicology Mechanisms and Methods, 19: 302-307.

14. Jangir, R. N. \& Jain, G. C. (2014). Diabetes Mellitus Induced Impairment of Male Reproductive Functions: A Review. Current Diabetes Reviews, 10(3) : 147-157.

15. Kianifard, D. (2016). Microscopic study of testicular tissue structure and spermatogenesis following long term dose dependent administration of monosodium glutamate in adult diabetic rats. Romanian Journal of Diabetes Nutrition \& Metabolic Diseases, 23(2): 147-158.

16. Kotian, S. R., Kumar, A., Mallik, S. B., Bhat, N. P., Souza, A. D. \& Pandey, A. K. (2019). Effect of Diabetes on the Male Reproductive System-A Histomorphological Study. Journal of Morphological Sciences, 36:17-23.

17. Linder, R. E., Strader, L. F., slot, V. L. \& Suarez, J. D. (1992). Endpoints of Spermatoxicity in the Rat after Short Duration Exposures 
to Fourteen Reproductive Toxicants. Reproductive Toxicology, 6: 491-505.

18. Maiorino, M. I., Bellastella, G., Della, Volpe, E., Casciano, O., Scappaticcio, L., Cirillo, P., Giugliano, D. \& Esposito, K. (2017). Erectile dysfunction in young men with type 1 diabetes. International Journal of Impotence Research, 29: 17-22.

19. Meyer, C., Stumvoll, M., Nadkarni, V., Dostou, J., Mitrakou, A. \& Gerich, J. (1998). Abnormal renal and hepatic glucose metabolism in type 2 diabetes mellitus. Journal of Clinical Investigation, 102: 619624.

20. Murray, F. T., Orth, J., Gunsalus, G., Weisz, J., Jefferson, L. S., Musto, N. A. \& Bardin, C. W. (1981). The pituitary-testicular axis in the streptozotocin diabetic male rat: evidence for gonadotroph, Sertoli cell and Leydig cell dysfunction. International Journal of Andrology, 4: 265-80.

21. Ngoula, F., Watcho, P., Dongmo, M. C., Kenfack, A., Kamtchouing, P. \& Tchamboué, J. (2007). Effects of Pirimiphos-methyl (an organophosphate insecticide) on the fertility of adult male rats. African Health Science, 7(1): 3-9.

22. OECD 416 (2001). Ligne directrice de l'OECD pour les essais de produits chimiques; Étude de toxicité pour la reproduction sur deux générations: $14 \mathrm{p}$.

23. Punthakee, Z., Goldenberg, R. \& Katz, P. (2018). Définition, classification et diagnostic du diabète, du prédiabète et du syndrome métabolique. Canadian Journal of Diabetes, 42: 10-15.

24. Rosen, R. C., Fisher, W. A., Eardley, I., Niederberger, C., Nadel, A. \& Sand, M. (2004). The multinational Men's Attitudes to Life Events and Sexuality (males) study: I. Prevalence of erectile dysfunction and related health concerns in the general population. Current Medical Research and Opinion, 20(5): 607-617.

25. Seethalakshmi, L., Menon, M. \& Diamond, D. (1987). The effect of streptozotocin-induced diabetes on the neuroendocrine-male reproductive tractaxis of the adult rat. The Journal of Urology, 138:190-194.

26. Shojaeii, S., Firoozabadi, A. D., Rasouli, M. B., Shahri, N. M. \& Haghparast, A. (2014). Morphological Evaluation of Testis Tissue of Rats in Various Time Points after Diabetes Type 1 Induction. Iranian Journal of Diabetes and Obesity, 5(3): 98-106.

27. Soltésová, D. \& Herichová, I. (2011). On the mechanisms of diabetogenic effects of alloxan and streptozotocin. Diabetologie, 14: 130-138. 
28. Steger, R. W., Amador, A., Lam, E., Rathert, J., Weis, J. \& Smith, M.S. (1989). Streptozotocin-induced deficits in sex behavior and neuroendocrine function in male rats. Endocrinology, 124: 1737-1743.

29. Sultan, C., Priolet, G., Benzard, Y., Rosa, R. \& Josso, F. (1982). Technique en hématologie $2^{\text {ème }}$ édition. Flammarion Méd. Sci., 15-32.

30. Szkudelski, T. (2001). The Mechanism of Alloxan and Streptozotocin Action in B Cells of the Rat Pancreas. Physiologica Research, 50: 536546.

31. Wherrett, D. K., Ho, J., Huot, C., Legault, L., Nakhla, M. \& Rosolowsky E. (2018). Diabète de type 1 chez les enfants et les adolescents. Canadian Journal of Diabetes, 42 : 234-246.

32. Yogev, L., Gottriech, A., Timan, B., Homonnai, Z. T. \& Paz G. F. (1985). - Changes in LH and prolactin levels in diabetic male rats and the role of the opiate system in the control of their secretion. Life Sciences, 37: 993-999.

33. Zougrou, N. E., Kouassi, K. A., Tahiri, A., Blahi, A. N. \& Kouakou K. (2018). Evaluation of the Effects of Aqueous Leaves Extract of Cnestis ferruginea from Côte d'Ivoire on Male Rat Reproductive System. European Journal of Medicinal Plants. 25(3): 1-16. 